\title{
Complex periodic limb movements during sleep or partial epileptic seizures?
}

\begin{tabular}{|llll|}
\hline Table Sleep measures before and after dopaminergic agonist treatment & \\
& Before treatment, night 1 & Before treatment, night 2 & Under treatment \\
\hline Total sleep time, $\min$ & 297 & 303 & 422 \\
\hline Sleep efficacy, \% & 46 & 52 & 78 \\
Latency to & & & \\
\hline Sleep onset, min & 270 & 197 & 41 \\
\hline REM sleep onset, min & 230 & 180 & 189 \\
\hline Sleep stages, \% & & & \\
\hline N1 & 33 & 25.7 & 20 \\
\hline N2 & 28 & 32.3 & 28 \\
\hline N3 & 3.7 & 20.4 & 22 \\
\hline REM sleep & 35.3 & 21.6 & 30 \\
\hline Periodic leg movements/h & 88 & 67 & 7 \\
\hline Periodic leg movements-related arousals/h & 76 & 49 & 4 \\
\hline
\end{tabular}

a Pramipexole $0.18 \mathrm{mg} / \mathrm{night}$.

A 69-year-old woman had insomnia, restless legs syndrome, and violent movements during sleep; she had had a generalized seizure several years previously. She underwent 4 days of video-EEG investigation for these movements (table, and figure e-1 on the Neurology ${ }^{\circledR}$ Web site at Neurology.org). There was no epileptic activity, but repetitive, stereotyped movements (88 movements/hour; movement duration: 2.5 seconds) occurred only during sleep, which were typical of periodic leg movements but associated with atypical, polyphasic hand cycling/rubbing movements (see video). This complex motor pattern might be confused with a focal epileptic seizure.

Treatment with pramipexole $(0.18 \mathrm{mg} / \mathrm{night})$ alleviated the insomnia and movements, arguing further for complex periodic leg (and arm) movements of sleep.

Vi-Huong Nguyen-Michel, MD, Ovidio Solano, MD, Virginie Lambrecq, MD, PhD, Sophie Dupont, MD, PhD, Claude Adam, MD, PhD, Isabelle Arnulf, $M D, P h D$

From the Epileptology Unit, Department of Neurology (V.-H.N.-M., O.S., V.L., S.D., C.A.), and the Sleep Disorders Unit, National Reference Center for Narcolepsy, Hypersomnia and Kleine-Levin Syndrome (I.A.), Pitié-Salpêtrière Hospital, Paris, France.

Author contributions: Dr. Nguyen-Michel: acquisition of data, interpretation of data, drafting/revising the manuscript for content. Dr. Solano: acquisition of data, interpretation of data, drafting/revising the manuscript for content. Dr. Lambrecq: acquisition of data, interpretation of data, drafting/revising the manuscript for content. Prof. Dupont: acquisition of data, interpretation of data, drafting/ revising the manuscript for content. Dr. Adam: acquisition of data, interpretation of data, drafting/revising the manuscript for content. Prof. Arnulf: interpretation of data, drafting/revising the manuscript for content, and study supervision. All coauthors have seen and approved the submitted version of the manuscript and accept responsibility for its content.

Study funding: No targeted funding reported.

Disclosure: The authors report no disclosures relevant to the manuscript. Go to Neurology.org for full disclosures.

Correspondence to Dr. Nguyen-Michel:vhnguyen.michel@gmail.com 


\section{Neurology}

\section{Complex periodic limb movements during sleep or partial epileptic seizures? \\ Vi-Huong Nguyen-Michel, Ovidio Solano, Virginie Lambrecq, et al. Neurology 2015;85;2180 \\ DOI 10.1212/WNL.0000000000002224}

\section{This information is current as of December 14, 2015}

\section{Updated Information \& Services}

Supplementary Material

\section{Subspecialty Collections}

Permissions \& Licensing

Reprints including high resolution figures, can be found at: http://n.neurology.org/content/85/24/2180.full

Supplementary material can be found at: http://n.neurology.org/content/suppl/2015/12/12/WNL.0000000000002 224.DC1

http://n.neurology.org/content/suppl/2015/12/12/WNL.0000000000002 224.DC2

This article, along with others on similar topics, appears in the following collection(s):

All Epilepsy/Seizures

http://n.neurology.org/cgi/collection/all_epilepsy_seizures

All Movement Disorders

http://n.neurology.org/cgi/collection/all_movement_disorders

All Sleep Disorders

http://n.neurology.org/cgi/collection/all_sleep_disorders

EEG

http://n.neurology.org/cgi/collection/eeg_

Restless legs syndrome

http://n.neurology.org/cgi/collection/restless_legs_syndrome

Information about reproducing this article in parts (figures,tables) or in its entirety can be found online at:

http://www.neurology.org/about/about_the_journal\#permissions

Information about ordering reprints can be found online:

http://n.neurology.org/subscribers/advertise

Neurology ${ }^{\circledR}$ is the official journal of the American Academy of Neurology. Published continuously since 1951, it is now a weekly with 48 issues per year. Copyright @ 2015 American Academy of Neurology. All rights reserved. Print ISSN: 0028-3878. Online ISSN: 1526-632X.

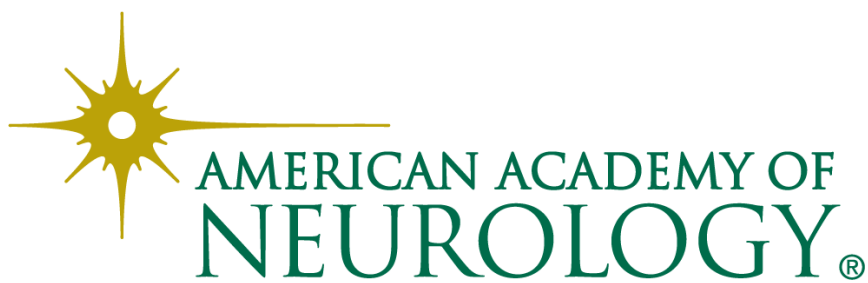

